\title{
RHEUMATOLOGICAL HAND AND FINGER SYMPTOMS
}

\author{
BY \\ ERIC JONSSON
}

Stockholm

Rheumatological symptoms in hands and fingers occur frequently and are very important in practice, but they have not received the attention in the literature which their significance deserves.

\section{Various Hand and Finger Symptoms}

The Usual Rheumatoid Arthritic Changes.-The hand symptoms occurring in ordinary rheumatoid arthritis are typical and well known: swelling of the Joints, muscular atrophy, ulnar deviations, subluxations, trophic disorders, etc. A characteristic feature is the symmetric spread of the joint changes.

Atypical Arthritic Changes.-An " atypical " form of rheumatoid arthritis has been described by this author (1946). It is characterized by the joint symptoms being asymmetrical. Muscular atrophy and consequent ulnar deviation do not occur to any great extent, nor do "trophic" skin symptoms. From the practical point of view it is important that there is little progressive tendency in these cases. The risk of invalidism is therefore smaller than with the common type of rheumatoid arthritis, despite the fact that the joint changes may be quite pronounced, so that large exudates and destructive changes are present in the interphalangeal joints. The sedimentation rate usually remains low for long periods, with the joint symptoms restricted to hands and feet. Nevertheless, in a few cases exacerbations and progress may be observed.

Osteoarthropathia Mutilans.-This is a strange phenomenon that may arise with rheumatoid arthritis, as well as in psoriatic arthropathy and in certain organic nerve diseases. It is characterized by particularly extensive destructive changes in the bone, so that the epiphyses and large parts of the diaphyses disappear. The remaining fragments of bone have usually a characteristic form with tapering pointed ends.

Osteo-arthropathia mutilans was described in 1913 by Pierre Marie and Léri in connexion with rheumatoid arthritis. Destructive changes in the bone cause shortening of the finger skeleton in relation to the skin and the soft parts; the result is that these crease like the segments in binoculars. Pierre Marie and Léri for this reason introduced the name of " main-en-lorgnette".

Pathologically Pierre Marie and Léri discovered $\rightarrow$ fatty degeneration in bone marrow and soft parts, $N$ hyperaemia of the subcutaneous tissues, and a $\mathrm{O}$ granulation tissue rich in vessels between the ends of the bones. There have since been descriptions $\bar{z}$ of a number of cases. Other joints besides the fingers may also be affected. The author published $\frac{5}{5}$ two cases of this type in 1938 and has sinee had the opportunity to observe some twenty more. In two tै cases it was possible (1947) to undertake histological investigations (Dr. F. Wahlgren, Head of the Pathological Department, Södersjuk-huset). The most striking feature was the high degree of bone atrophy. The spongy tissue with its trabecula was almost entirely gone, and the inside of the bone was filled with fat marrow. Even the cortex was highly atrophic and was represented only by a-shell as thin as paper.

Psoriasis.-The connexion between psoriasis and rheumatoid arthritis is not quite clear. Some consider that the occurrence of rheumatoid arthritic symptoms with psoriasis is only an accidental coincidence of two common affections. Others assume that there is a causal connexion and that therefore a real psoriatic arthropathy exists, which attacks hands and feet particularly and especially the distal interphalangeal joint. Changes in the nails are common, and mutilating changes are seen now and then in such cases.

Finger Oedema.- This may be present in inflam- $N$ matory conditions in the hands in rheumatoid $N$ arthritis, and also in climacteric arthritis and, $\omega$ according to Kahlmeter (1936), it may be associated with stiff shoulders. Finger oedema is seen also, $\stackrel{\varrho}{\subset}$ together with changes in the palmar aponeurosis, $\stackrel{\odot}{\oplus}$ in the Ask-Upmark (1944) arm-hand-finger syndrome in cardiac affections.

Heberden's Nodes.-These, of course, do not $\frac{}{\Phi}$ usually give trouble, but occasionally pain may be $\frac{?}{\mathbb{Q}}$ present. This is often relatively insignificant and 
transitopy. Occasionally the Heberden nodes perforate and a thick jelly-like mass is evacuated. This phenomenon has been described by Gross (1937), under the name of "degenerative myxomatous cysts of the synovia". Surgical treatment does not appear to be indicated. In the cases the author has had occasion to observe, the perforation opening closed up spontaneously.

Bouchard's Nodes.- These are of the same nature and about of the same size and appearance as the Heberden nodes, but are located on the proximal interphalangeal joints. Both Bouchard and Heberden nodes are more common in women than in men, and likewise osteo-arthritis in the carpometacarpal and the metacarpo-phalangeal joints of the thumb; but the tendency is for osteo-arthritis in the other joints of the fingers to occur mostly in men.

Knuckle Pads (Garrod, 1893).-These consist of protuberances about half the size of a pea on the dorsal aspect of the proximal interphalangeal joints. They are of firm consistency and move freely over the joint, which is not affected, but they adhere to the skin and there may be slight pain and a feeling of tension when the finger is bent. In the author's opinion excision may sometimes be indicated, but it does not always ensure freedom from trouble. If subjective signs are present the cases are most often wrongly diagnosed as rheumatoid arthritis. The differential diagnosis is not made easier for the inexperienced by the fact that rheumatic nodes of the same macroscopic appearance and with the same localization may be present in rheumatoid arthritis.

Since Garrod's publication, knuckle pads have also been described by Parkes Weber (1938), Wessling (1937), Kranz (1938), and others. Many of Garrod's cases had Dupuytren's contracture, and in some of them this affection occurred in the family. Two of the author's cases displayed changes that entirely agree with those in Dupuytren's contracture (Dr. F. Wahlgren). In others a fibroma-like histological picture was present. According to Lund (1941), Dupuytren's contractures and knuckle pads are often encountered in epileptics. The designation "helodermia" employed by many authors is incorrect, according to Kranz (1938), as this indicates another affection.

Hyperkeratoses. - The hyperkeratoses on the basal interphalangeal joints are of quite another nature from knuckle pads. They may be massive, and they are possibly identical with the changes described by Moncorps (1936-37) under the name of "keratosis supracapitularis pulvinata".

Tendinitis Nodosa.-Tendinitis nodosa in the fingers occurs, of course, as an isolated phenomenon, but nodular tendinitis is also common in rheumatoid arthritis. Quervain's tendinitis, tendovaginitis stenosans, is a constriction of the radial tendon sheath under the dorsal carpal ligament and gives rise to characteristic symptoms.

Arthralgia in the fingers and joints of the hands is often met with, especially in younger women (Jonsson, 1946a). For the reason that rheumatoid arthritis may start with similar symptoms, the differential diagnosis is not always easy. Consequently such cases are often wrongly diagnosed. The same is the case with myalgia in the hand musculature.

Congenital Anomalies.-Congenital hand and finger anomalies do not generally present much of rheumatological interest. An exception is constituted by " hammer fingers", an anomaly consisting in the fifth finger on both hands being acutely flexed at the basal interphalangeal joint and hyperextended at the metacarpo-phalangeal joint. These cases are often diagnosed as rheumatoid arthritis.

\section{Summary}

Rheumatological hand and finger symptoms are common and important in practice.

The hand symptoms in ordinary rheumatoid arthritis are well known. An atypical form of rheumatoid arthritis is described by the author, and its characteristics include asymmetrical joint symptoms and absence of atrophic symptoms. The joint changes may be quite pronounced, but are usually restricted to hands and feet; the tendency to progression is slight.

Reference is made to osteoarthropathia mutilans. The author has had an opportunity to investigate two cases histologically. The most striking feature was the high degree of bone atrophy.

Finger oedema, Heberden and Bouchard nodes, and, knuckle pads (Garrod) are mentioned. The connexion between knuckle pads and Dupuytren's contracture described by Garrod is illustrated by the author, who in two cases of knuckle pads found histological changes similar to those in Dupuytren's contracture.

Brief mention is made of a number of other hand and finger symptoms of rheumatological interest, including arthralgia of the fingers and joints of the hands (author). Such cases are often wrongly diagnosed as rheumatoid arthritis and have, therefore, a practical importance.

\section{REFERENCES}

Ask-Upmark, E. (1944). Nord. Med., 21, 434.

Garrod, A. E. (1893). St. Barts. Hosp. Rep., 29, 157. (1904). Brit. med. J., 2, 8. 
Gross, R. E. (1937). Surg. Gynec. Obstet., 65, 289.

Jonssion, E. (1947). Nord. Med., 36, 2287. (1946a). Acta med. scand., 123, 529. (1946b). Nord. Med., 29, 189. (1938). Acta med. scand., 96, 28.

Kahlmeter, G. (1936). Nord. Med., 12, 1435.

Kranz, W. (1938). Derm. Wschr., 107, 945.

Lund, M. (1941). Acta psychiat. Kbh., 16, 465.

Marie,. P., and Léri, A. (1913). Bull. Soc. méd. Hop. Paris, 36, 104.

Moncorps, C. (1936-37). Zbl. Haut- Geschl. krankh., 54, 291.

Parkes Weber, F. (1938). Brit. J. Derm. Syph., 50, 26.

Wessling, J. (1937). Derm. Wschr., 105, 956.

\section{Manifestations Rhumatismales au Niveau de la Main et des Doigts \\ RÉSUMÉ}

Dans la pratique les manifestations rhumatismales au niveau de la main et des doigts sont communes et importantes.

L'atteinte de la main est bien connue dans l'arthrite rhumatismale. L'auteur décrit une forme atypique d'arthrite rhumatismale, dont les caractéristiques comprennent des manifestations articulaires asymétriques et l'absence de troubles trophiques. Les modifications articulaires peuvent être très marquées, mais sont généralement limitées aux mains et aux pieds, avec faible tendance progressive.

L'auteur mentionne les oedèmes des doigts, les nodules d'Heberden et de Bouchard, et les nodosités articulaires (Garrod). Le rapport entre les nodosités articulaires et la contracture de Dupuytren décrite par Garrod est illustrée par l'auteur qui a trouvé, dans deux cas de ces nodosités, des lésions histologiques semblables à celles qui sont décrites dans la contracture de Dupuytren.

L'auteur mentionne brièvement un certain nombre de manifestations rhumatismales au niveau de la main et des doigts présentant un intérêt au point de vue rhumatologique, notamment l'arthralgie des doigts et des articulations de la main. Ces manifestations sont souvent et à tort considérées comme des cas d'arthrite rhumatismale et ont donc une importance pratique.

\section{INTERNATIONAL CONGRESS ON RHEUMATIC DISEASES}

More than 150 physicians from foreign countries are expected at the International Congress on Rheumatic Diseases to be held at the Waldorf Astoria in New York City from May 30 to June 3, - 1949. Many of these physicians will present papers before the plenary sessions which will be held in the mornings. In the afternoons clinics will be held at several of the New York hospitals.

Papers to be read before the Congress will include, in addition to presentations by prominent U.S. authorities, many by distinguished foreign guests, among them being
Lord Horder (London), Jacques Forestier (Aix-les-Bains, France), Eric Jonsson (Stockholm), Imre Barsi-Basch (Budapest), Prof. S. de Seze (Paris), Svend Clemmesen (Copenhagen), William Tegner (London), Henrik Seyfarth (Oslo), P. Barcelo (Barcelona), Veikko Laine (Heinolan, Finland), and Fernando H. Ramos (Montevideo).

The official languages of the Congress will be English, French, and Spanish, but instantaneous translations of the scientific papers given at the plenary sessions will be made by means of the I.B.M. wireless system. The meeting is open, and the registration fee is $\$ 10.00$. 